\title{
Facile Synthesis of Carbon Nanospheres with High Capability to Inhale Selenium Powder for Electrochemical Energy Storage
}

\author{
Mustafa Khan ${ }^{1}$, Xuli Ding ${ }^{2, * \mathbb{C}}$, Hongda Zhao ${ }^{2}$, Xinrong Ma ${ }^{2}$ and Yuxin Wang ${ }^{1, *(1)}$ \\ 1 School of Materials Science and Engineering, Jiangsu University of Science and Technology, \\ Zhenjiang 212100, China; mkhan.esd@gmail.com \\ 2 School of Science, Jiangsu University of Science and Technology, Zhenjiang 212100, China; \\ zhd787278660@163.com (H.Z.); maxinrong2021@163.com (X.M.) \\ * Correspondence: xuliding@just.edu.cn (X.D.); ywan943@163.com (Y.W.)
}

check for

updates

Citation: Khan, M.; Ding, X.; Zhao, H.; Ma, X.; Wang, Y. Facile Synthesis of Carbon Nanospheres with High Capability to Inhale Selenium Powder for Electrochemical Energy Storage. Materials 2021, 14, 6760. https://doi.org/10.3390/ma14226760

Academic Editors: Kunal Mondal,

Prasad S. Raut and Alexander N. Obraztsov

Received: 8 July 2021

Accepted: 19 August 2021

Published: 10 November 2021

Publisher's Note: MDPI stays neutral with regard to jurisdictional claims in published maps and institutional affiliations.

Copyright: (c) 2021 by the authors. Licensee MDPI, Basel, Switzerland. This article is an open access article distributed under the terms and conditions of the Creative Commons Attribution (CC BY) license (https:/ / creativecommons.org/licenses/by/ $4.0 /)$.

\begin{abstract}
Carbon-selenium composite positive electrode (CSs@Se) is engineered in this project using a melt diffusion approach with glucose as a precursor, and it demonstrates good electrochemical performance for lithium-selenium batteries. X-ray diffraction (XRD) and scanning electron microscopy (SEM) with EDS analysis are used to characterize the newly designed CSs@Se electrode. To complete the evaluation, electrochemical characterization such as charge-discharge (rate performance and cycle stability), cyclic voltammetry (CV), and electrochemical impedance spectroscopy (EIS) tests are done. The findings show that selenium particles are distributed uniformly in mono-sized carbon spheres with enormous surface areas. Furthermore, the charge-discharge test demonstrates that the CSs@Se cathode has a rate performance of $104 \mathrm{~mA} \mathrm{~h} \mathrm{~g}^{-1}$ even at current density of $2500 \mathrm{~mA} \mathrm{~g}^{-1}$ and can sustain stable cycling for 70 cycles with a specific capacity of $270 \mathrm{~mA} \mathrm{~h} \mathrm{~g}^{-1}$ at current density of $25 \mathrm{~mA} \mathrm{~g}^{-1}$. The homogeneous diffusion of selenium particles in the produced spheres is credited with an improved electrochemical performance.
\end{abstract}

Keywords: carbon nanospheres; selenium; Li-Se battery

\section{Introduction}

Due to the increasing environmental damage caused by the massive burning of coal, gasoline, and natural gas, there is a growing demand for the effective use of clean energy. Storage of energy is critical for a clean energy system. The ever-increasing need for energy storage can be met by rechargeable batteries with high specific capacity and energy density [1-5]. Due to their high specific energy density and specific capacity, lithium-sulfur batteries are popular among diverse battery systems [6,7]. However, the weak conductivity of sulfur, the considerable volume change during lithium-ion insertion and extraction, and the dissolution of intermediary polysulfides limit their practical application. As a result, much effort has been expended in the hunt for novel cathode materials for rechargeable lithium batteries [8].

Selenium, which has electrochemical characteristics comparable to sulfur, can produce selenides when it reacts with lithium. Selenium has a theoretical gravimetric capacity of roughly $670 \mathrm{~mA} \mathrm{~h} \mathrm{~g}^{-1}$, which is lower than sulfur (S), but its higher density compensates for this shortcoming. Furthermore, selenium has a higher electrical conductivity $\left(1 \times 10^{-3} \mathrm{~S} \mathrm{~m}^{-1}\right)$ than sulfur $\left(5 \times 10^{-28} \mathrm{~S} \mathrm{~m}^{-1}\right)[9,10]$ resulting in good rate and cyclic performance without the requirement for a large amount of conductive carbon. Due to these properties, selenium is a good contender for high energy positive electrode material [11]. However, selenium, like sulfur, is susceptible to the dissolution of higher order polyselenides, resulting in rapid capacity degradation, low coulombic efficiency, and poor cyclic performance. Several experiments have been proposed by researchers in recent years to solve these challenges; among these tests, creating a carbon-selenium composite cathode proves to be a good strategy [12,13]. These composites not only diminish the shuttle effect 
induced by unwanted polyselenides, but they also improve electrical conductivity [14-25]. Much work has been done in recent years to construct the carbon-selenium from various carbonaceous materials such as CNTs, PAN [14], and others [26]. Wu et al. [12] developed a carbon-selenium composite by low-temperature ball milling of a Se/PAN combination, which demonstrated a discharge capacity of $244 \mathrm{~mA} \mathrm{~h} \mathrm{~g}^{-1}$ at $100 \mathrm{~mA} \mathrm{~g}^{-1}$ after 10 cycles. Abouimrane et al. [27] created a selenium-carbon nanotube (Se/CNT) composite as a positive electrode material with a reversible capacity of $350 \mathrm{~mA} \mathrm{~h} \mathrm{~g}^{-1}$ at $50 \mathrm{~mA} \mathrm{~g}^{-1}$ current density.

Despite the fact that the performance of selenium composite cathodes has increased over time, there is still insufficient contact between the active material and the electronic conductors. Many attempts have been made to improve the electrochemical performance of lithium-selenium batteries; for example, a porous carbon structure has proven to be an effective positive electrode. Wang et al. [28] injected selenium into porous carbon to create a carbon-selenium composite that performed well at $600{ }^{\circ} \mathrm{C}$. However, this is a timeconsuming and complex technology, and the present requirement is to design a simple yet effective synthesis procedure. Carbon spheres (CSs) are produced in this contribution using a simple, one-step hydrothermal technique. The carbon-selenium composite improves electrochemical performance when used as a positive electrode. The favorable profiles are due to the incorporation of selenium powder into the CSs, which results in the reduced development of the intermediary polyselenides, which normally dissolve in the electrolytes and cause capacity fading.

\section{Experimental Section}

Synthesis of CSs@Se: All the chemical reagents used in this experiment were purchased from Sigma Aldrich and were not purified further. Carbon spheres (CSs) were created using a straightforward one-step hydrothermal procedure. A known amount of glucose $(11.2 \mathrm{~g})$ was introduced to $130 \mathrm{~mL}$ of de-ionized water and swirled for half an hour with a constant magnetic stirrer to achieve uniform dispersion. The solution was then poured to two Teflon-lined autoclaves ( $100 \mathrm{~mL}$ each), and the reaction was carried out in a vacuum oven at $180^{\circ} \mathrm{C}$ for $6 \mathrm{~h}$ to obtain a regular and uniform shape. The autoclaves were then cooled naturally in air to room temperature, and the black solid precipitates were recovered by centrifuge after three washes with ethanol and water (three times each) and desiccated at $80^{\circ} \mathrm{C}$ for $12 \mathrm{~h}$ (named CSs) in a vacuum oven. To produce CSs@Se, known quantities of carbon spheres and selenium powder (1:2 mass ratio) were mashed together. The mixture was then transferred to a tubular furnace (OTF-1200X) and heated at a rate of $5^{\circ} \mathrm{C} \mathrm{min}-1$ up to $400{ }^{\circ} \mathrm{C}$, remaining for $3 \mathrm{~h}$ in an $\mathrm{Ar} / \mathrm{H}_{2}$ protection gas. Following that, a sample of CSs@Se was obtained through natural cooling. The synthesized materials were characterized using different microstructural techniques and electrochemical tests for $\mathrm{Li}-\mathrm{Se}$ batteries.

\section{Material Characterization}

Using a field-emission scanning electron microscope (FESEM, JEOL JMS-7001-F, JEOL, Tokyo, Japan), we determined the structure and morphology of CSs and CSs@Se composite. The EDS instrument installed in the SEM was used to determine the elemental mapping of the elements. The phase composition of the material was determined using an X'Pert PRO diffractometer (XRD, Shimadzu, Kyoto, Japan: $\mathrm{XRD}-6000, \mathrm{Cu}-\mathrm{K} \alpha$ radiation, $0.15406 \mathrm{~nm}$, $\lambda=1.5406 \AA$ ), with the measuring angle ranging between $5-70^{\circ}$ and a scanning rate of $0.8^{\circ} / \mathrm{s}$. The thermogravimetry (TG) examination was carried out using a vertical zero friction dilatometer L75VS Linseis (Selb, Germany) at temperatures ranging from 30 to $800{ }^{\circ} \mathrm{C}$ in an argon environment in order to determine the selenium weight percent contained in the composite material, and the surface area of the material was calculated using the Brunauer-Emmett-Teller (BET) (ASAP2020) technique. 


\section{Electrochemical Characterization}

Using a half-cell, the electrochemical performance of bare carbon spheres (CSs) and CSs@Se composite was investigated. The cathodes were made by combining 70 weight percent active material (CSs/CSs@Se), 10 weight percent PVDF binder, and 20 weight percent carbon black (Super-P). A small amount of N-methyl pyrrolidone (NMP) was also added to the mixture, which was then agitated for $12 \mathrm{~h}$ with a continual magnetic stirrer to achieve a homogenous mixture. Finally, this homogeneous mixture (slurry) was applied on the foil (copper). The coated foil was then dried overnight at $60^{\circ} \mathrm{C}$. The foil was punched into disc shapes to make electrodes. The anode was a lithium foil disc with a $1 \mathrm{M} \mathrm{LiPF}_{6}$ solution in an electrolyte mixture of Ethyl carbonate (EC) and Diethyl carbonate (DEC) $(1: 1, v / v)$ and a porous Celgard 2400 separator. Half-cells were produced in a glove box with argon flowing $\left(\mathrm{H}_{2} \mathrm{O}<0.1 \mathrm{PPM}, \mathrm{O}_{2}<0.1 \mathrm{PPM}\right)$, then left for $8 \mathrm{~h}$ before being tested for electrochemical performance. The LAND battery testing station was used to undertake rate performance and cyclic stability tests in the voltage range of $0.005-3 \mathrm{~V}\left(\mathrm{vs} . \mathrm{Li} / \mathrm{Li}^{+}\right)$at various current densities. For the first five cycles, a cyclic voltammogram (CV) test was performed on workstation CH1611E with a voltage window of $0.005-3 \mathrm{~V}$ at $0.5 \mathrm{mV} / \mathrm{s}$. The coin cell impedance was measured at $10 \mathrm{mV}$ over a frequency range of $0.001-100,000 \mathrm{~Hz}$.

\section{Results and Discussion}

Low and high magnification SEM pictures of bare carbon spheres are shown in Figure 1a,b. Carbon spheres are homogeneous with surface area of $23.59 \mathrm{~m}^{2} / \mathrm{g}$, as shown in Figure 2a. Figure 1c shows selenium-loaded carbon spheres; loading of the selenium is confirmed by the EDS analysis. The elemental mapping of the CSs@Se composite is shown in Figure $1 \mathrm{~d}-\mathrm{f}$, indicating that carbon and selenium oxides are also generated during the synthesis process, though in modest amounts.
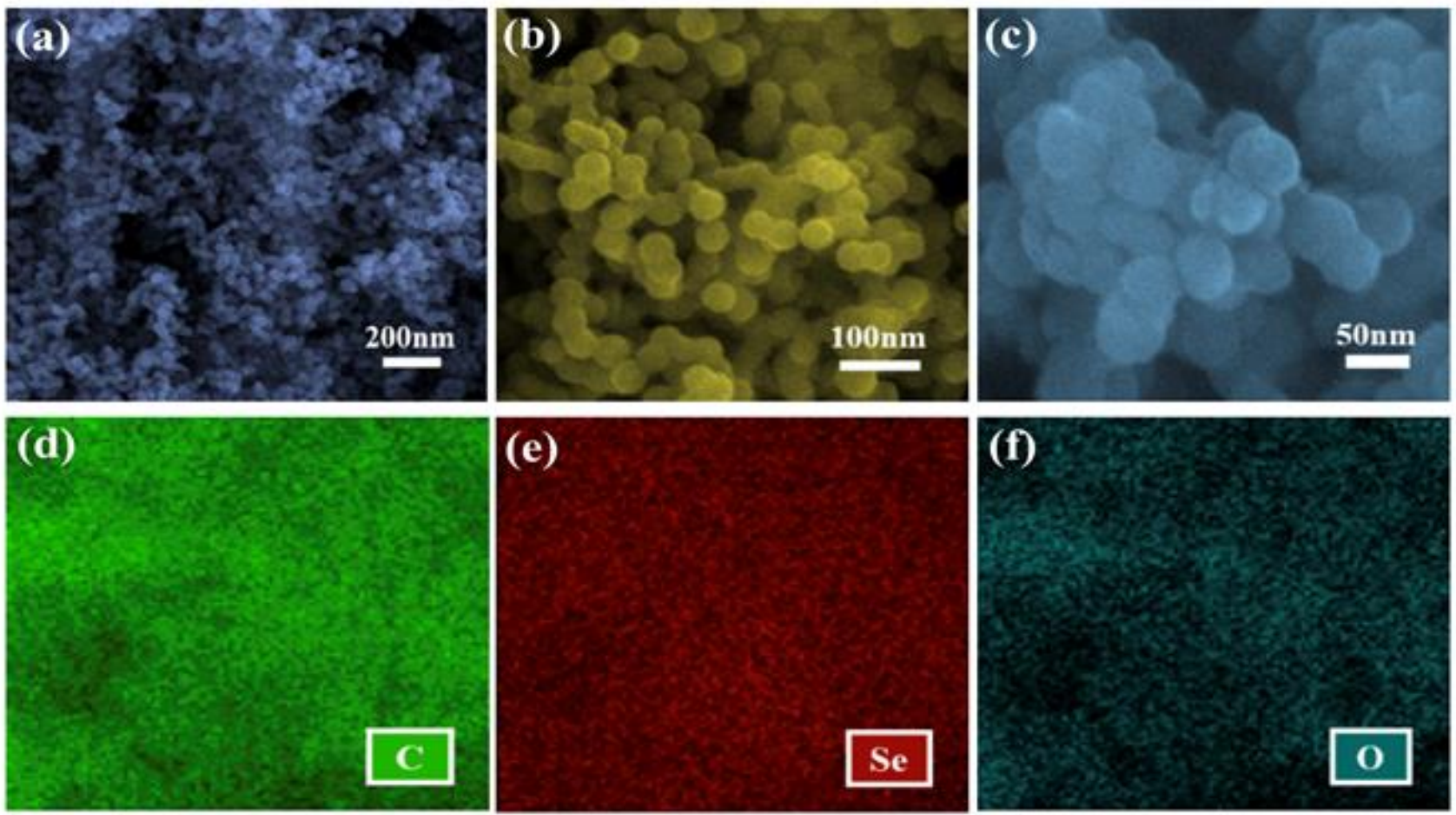

Figure 1. Morphology of bare carbon spheres and CSs@Se composite: (a,b) low and high magnification SEM images of bare carbon spheres, (c) high magnification surface morphology of CSs@Se composite, (d-f) EDS mapping of the CSs@Se showing the presence of carbon $(\mathrm{C})$, selenium (Se), and oxides $(\mathrm{O})$, respectively. 

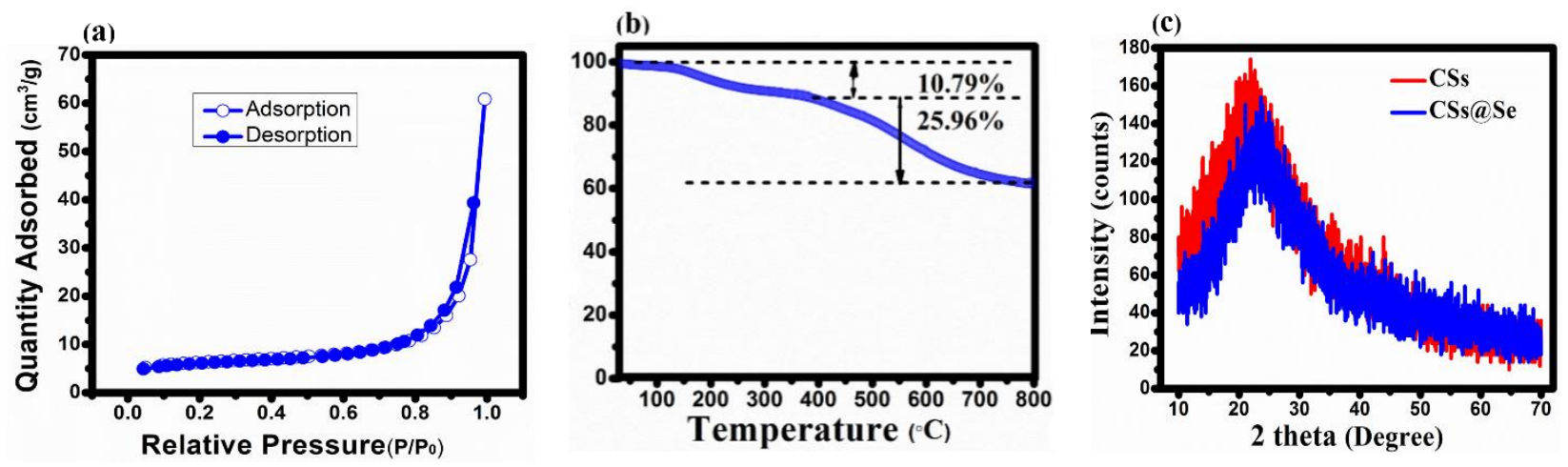

Figure 2. (a) Nitrogen adsorption and desorption isotherm of CSs, (b) TGA curve of CSs@Se composite, and (c) XRD pattern of CSs and CSs@Se composite.

TGA of CSs@Se composite was conducted in Figure 2b. A weight loss of 10.79 wt $\%$ below $350^{\circ} \mathrm{C}$ could be attributed to the evaporation of moisture absorbed in pores. From 350 to $800{ }^{\circ} \mathrm{C}$, the weight loss of $25.9 \mathrm{wt} \%$ was due to the removal of heteroatoms and the evaporation of selenium contents in the composite. The Gibbs free energy equation is as follows:

$$
\Delta \mathrm{G}_{\mathrm{B}}=4 \pi \sigma\left(\mathrm{r}^{2}-\frac{2 \mathrm{r}^{3}}{3 \mathrm{r} /}\right)
$$

where $\Delta G_{B}$ is Gibbs free energy, $r$ is the radius of carbon spheres, $\sigma$ is the interfacial tension, and $\mathrm{r} /$ is the critical radius [29]. At the beginning of the hydrothermal process at $180{ }^{\circ} \mathrm{C}, \Delta \mathrm{G}_{\mathrm{B}}>0$ and $\mathrm{r}^{\prime}<\mathrm{r}$ form an embryo, but as time passes, the system's Gibbs free energy decreases, resulting in the development of carbon nuclei with radius $r$. X-ray diffraction (XRD) was performed to check if selenium has been successfully loaded in to carbon spheres (Figure 2c). The bare carbon spheres (CSs) show a large diffraction peak at 2 theta $=22.3^{\circ}$; this peak can be indexed to 002 plane, which indicates that CSs are in amorphous phase [30]. After loading of the selenium, no new peak is observed because all selenium is absorbed into the pores. There is small shift in the peak at 2 theta $=23.76^{\circ}$, which are caused by the high temperature and impinging of the selenium into the pores.

The electrochemical testing of a CSs@Se composite positive electrode for lithiumselenium (Li-Se) batteries is performed with a 2032 type coin cell and a lithium foil negative electrode. The cyclic voltammetry (CV) curves of CSs@Se composite at $0.5 \mathrm{mV} \mathrm{s}^{-1}$ for five cycles from 0.005-3 V (vs. $\mathrm{Li}^{+} / \mathrm{Li}$ ) are shown in Figure 3a. As demonstrated in Figure 3a, the reduction in selenium into insoluble $\mathrm{Li}_{2} \mathrm{Se}$ corresponds to one cathodic peak centered at $1.03 \mathrm{~V}$ for the first curve (black one). The occurrence of only one peak indicates that no polyselenides phase exists during the lithiation process and hence no shuttle effect. The presence of two anodic peaks at 1.07 and $2.3 \mathrm{~V}$ (for the first curve) suggests that the reduced $\mathrm{Li}_{2} \mathrm{Se}$ was oxidized back during the de-lithiation process. After the first cycle, the anodic and cathodic peaks at 1.07 and $2.6 \mathrm{~V}$ have little displacement around $0.96 \mathrm{~V}$ for the second cycle, and for the other cycle, the curves practically coincide, indicating that CSs@Se composites are reversible. The charge-discharge pattern at various current values is shown in Figure $3 \mathrm{~b}$. The initial discharge curve shows a single slope voltage plateau at $1.03 \mathrm{~V}$, which best matches the $\mathrm{CV}$ result and demonstrates single-phase selenium conversion into insoluble $\mathrm{Li}_{2} \mathrm{Se}$. After the first discharge curve, the slope voltage for the others shifts somewhat. The slope voltage plateaus on the charge curves correlate to the two peaks on the cyclic voltammetry curve. 
(a)

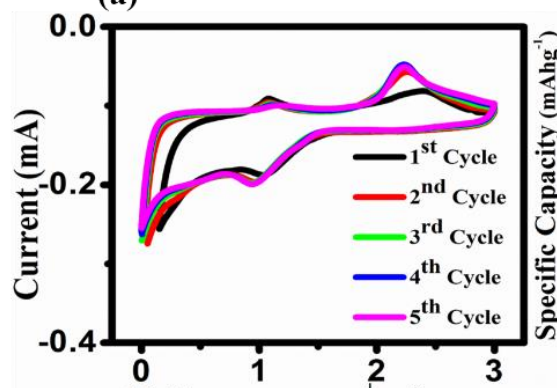

(b) Voltage (V) vs. Li $\left.{ }^{+} / \mathrm{Li}\right)$

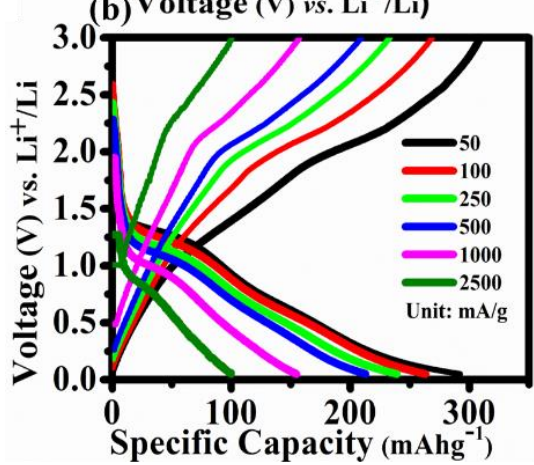

(c)

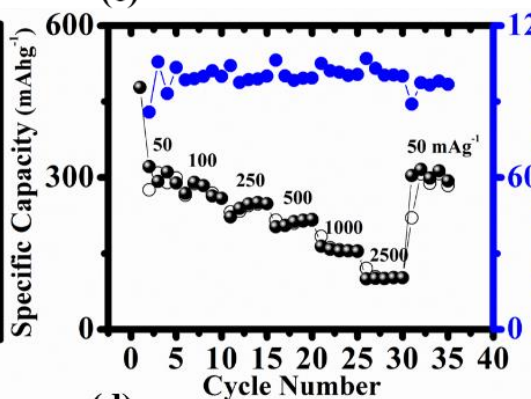

(d)

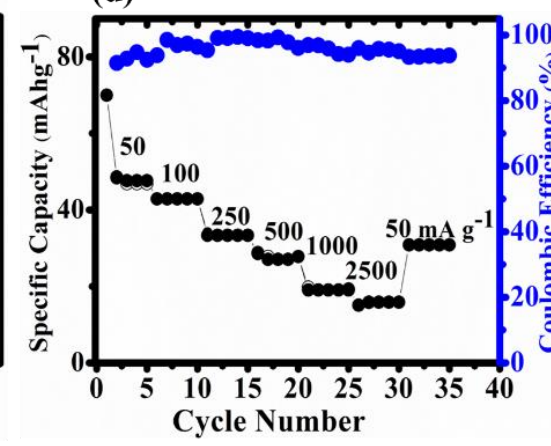

(e)

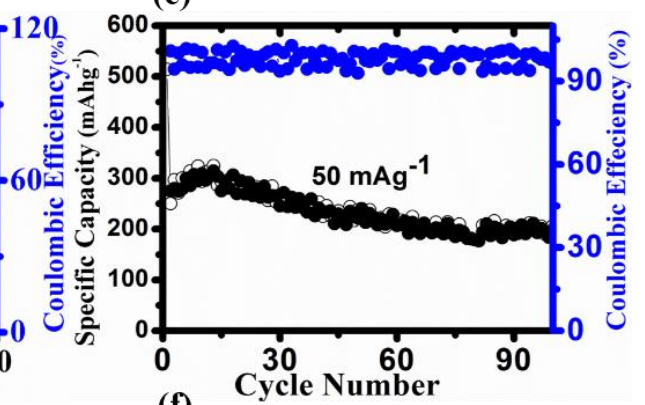

(f)

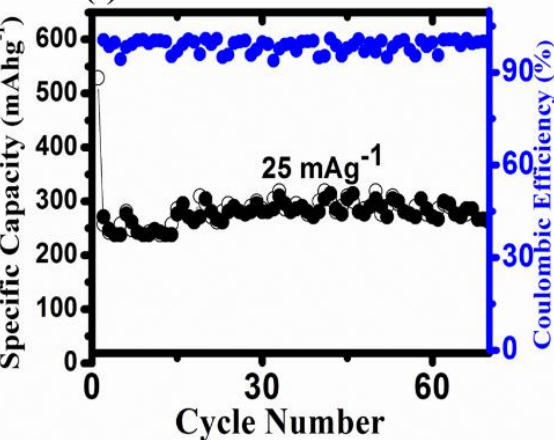

Figure 3. Electrochemical characterization of CSs@Se and CSs: (a) cyclic voltammetry (CV) of composite between 0.005-3 V at $0.5 \mathrm{mV} \mathrm{s}^{-1},(\mathbf{b})$ charging-discharging profiles of CSs@Se at different current rates (50-500 mA g ${ }^{-1}$ ), (c) rate performance of CSs@se (d) rate performance of CSs, (e) cyclic stability after 100 cycles of CSs@Se at $50 \mathrm{~mA} \mathrm{~g}^{-1}$, and (f) cyclic stability after 70 cycles of CSs@Se at current density of $25 \mathrm{~mA} \mathrm{~g}^{-1}$.

Meanwhile, Figure 3c,d exhibit the rate performances of CSs@Se composite and CSs at various current densities $\left(50 \mathrm{~mA} \mathrm{~g}^{-1}\right.$ to $2500 \mathrm{~mA} \mathrm{~g}^{-1}$ ). The composite cathode has an average specific capacity (at current densities) of $294\left(50 \mathrm{~mA} \mathrm{~g}^{-1}\right), 279\left(100 \mathrm{~mA} \mathrm{~g}^{-1}\right)$, $244\left(250 \mathrm{~mA} \mathrm{~g}^{-1}\right), 209\left(500 \mathrm{~mA} \mathrm{~g}^{-1}\right), 156\left(1000 \mathrm{~mA} \mathrm{~g}^{-1}\right)$, and $104 \mathrm{~mA} \mathrm{~h} \mathrm{~g}^{-1}\left(2500 \mathrm{~mA} \mathrm{~g}^{-1}\right)$. Furthermore, when the current returns to its initial amount, a specific capacity of $290 \mathrm{~mA} \mathrm{~h} \mathrm{~g}^{-1}$ is measured, demonstrating that the CSs@Se composite, as a positive electrode, is highly reversible. At the same current densities as above, the capacities of the bare CSs are $47.8,43.06,32.6,26.6,18.4$, and $14.9 \mathrm{~mA} \mathrm{~h} \mathrm{~g}^{-1}$. Figure $3 \mathrm{~b}$ depicted the equivalent chargedischarge curves at various current rates. The voltage curve is shown to be reduced at high current values as the current density increases to $2500 \mathrm{~mA} \mathrm{~g}^{-1}$. Due to the limited electrochemical kinetics in the CSs@Se electrode, the $\mathrm{Li}^{+}$are not fully intercalated into the CSs@Se composite at higher densities. Figure 3e,f depict the composite's cycle performance. The specific capacity of $190 \mathrm{~mA} \mathrm{~h} \mathrm{~g}^{-1}$ was preserved at $50 \mathrm{~mA} \mathrm{~g}^{-1}$ for 100 cycles, but the specific capacity of $270 \mathrm{~mA} \mathrm{~h} \mathrm{~g}^{-1}$ was preserved at $25 \mathrm{~mA} \mathrm{~g}^{-1}$.

In addition, the rate performance of the current CSs@Se composite is compared to other materials, such as S/C composite [31], G-Se@CNT [14], Se-AC composite [19], GO@Se@Ni [32], Se-SAC-NR [33], Se/MCN [17], pristine selenium [34], selenium nanowires [35], and Se@CNFs [36]. The comparison in Figure 4 shows that the rate performance of the CSs@Se composite outperforms the previously reported values. This is primarily due to the incorporation of selenium into the carbon spheres, the good consistency of the size of the carbon spheres, the creation of less polyselenide, and the absence of the shuttle effect. 

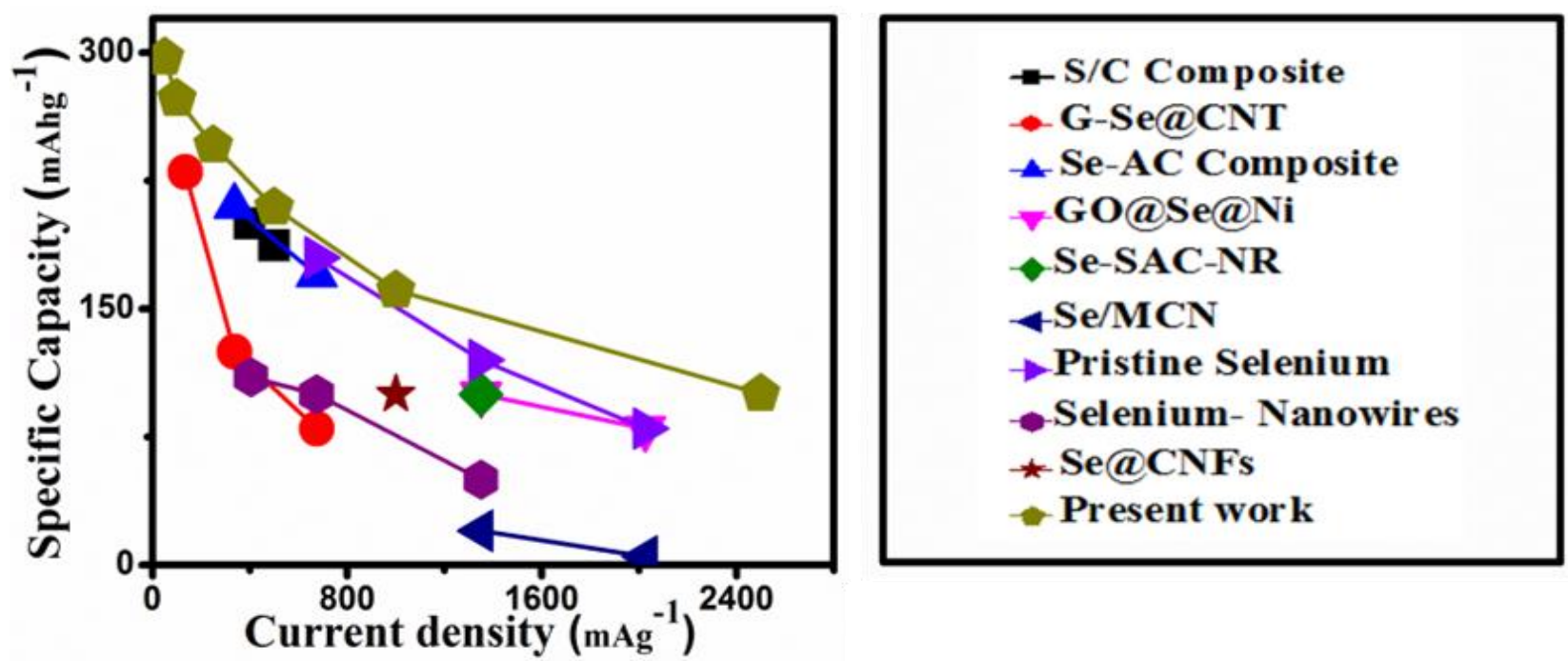

Figure 4. Comparison of current work (rate performance) with that of previously discussed results [15,20,32-37] on Li-Se battery.

The EIS analysis was then used to look into the charge transferred resistance (Rct) and diffusion coefficient (D) of $\mathrm{Li}^{+}$in the composite. The Rct for CSs@Se composite before and after 70 cycles is shown in Figure 5a. Additionally, according to $\mathrm{Z}$ view software analysis, the Rct values for the CSs@Se composite are $338 \Omega$ before cycling, which is significantly lower than the composite after 70 cycles $(789 \Omega)$. It shows that, as the number of cycles grows, the diffusion resistance increases, implying that Li ions bear less polarization during intercalation into the CSs@Se composite. Furthermore, Table 1 illustrates the various circuit values of the composite before cycling. Moreover, the diffusion coefficient (D) for $\mathrm{Li}^{+}$can be calculated from the slopes of $\omega^{-1 / 2}$ and $Z^{\prime}$ (Figure $5 b$ ), where the slope is proportional to the square of the Warburg factor as follows:

$$
\mathrm{D}_{\mathrm{Li}}+\propto 1 / \sigma^{2}
$$

(a)

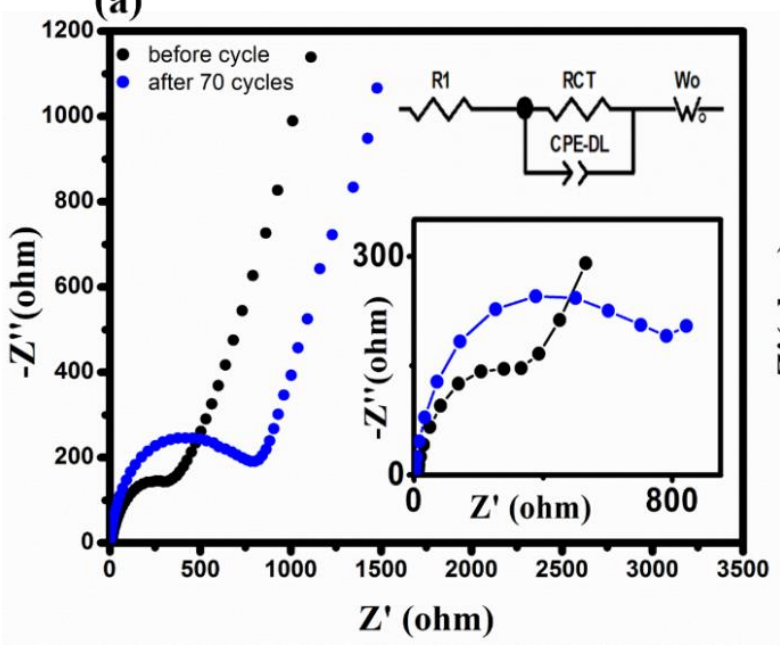

(b)

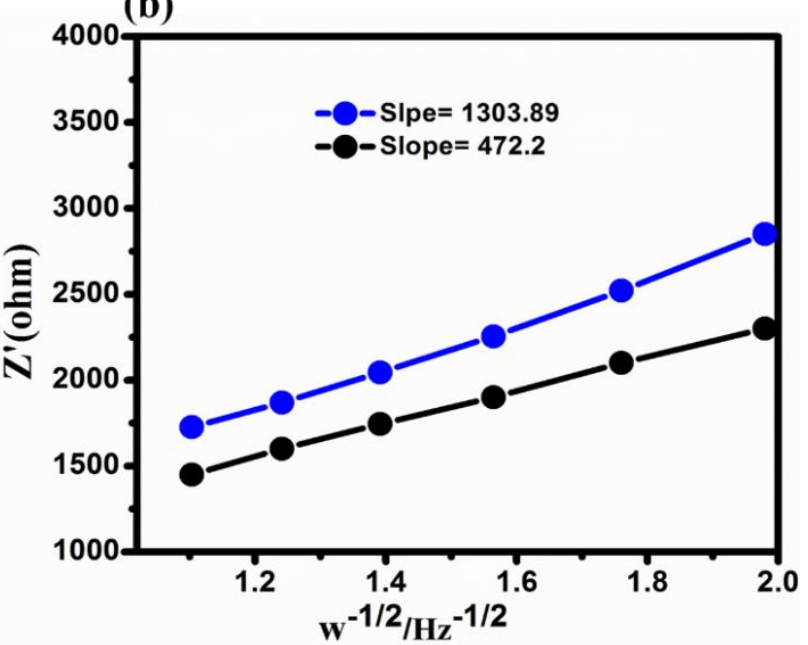

Figure 5. (a) The Nyquist plot of CSs@Se composite before and after cycling with Rct values plotted and equivalent circuit inserted. (b) Fitted lines of impedance, $Z^{\prime}$ vs. angular frequency $\mathrm{w}^{-1 / 2}$ (before cycling and after 70 cycles). 
Table 1. Shows the different circuit element values for CSs@Se composite before cycling.

\begin{tabular}{ccc}
\hline R1 & RS & CPE-DL \\
\hline $2.5 \Omega$ & $338 \Omega$ & $4 \times 10^{-5} \mathrm{~F}$ \\
\hline
\end{tabular}

This equation is utilized to determine the diffusion coefficient for the composite before and after cycling [37-40], and the obtained values for the $\sigma$ for fresh and for the cell after 70 cycles are 472.2 and 1303.89, respectively, as illustrated in Figure 5b.

\section{Conclusions}

A simple hydrothermal procedure was used to successfully create CSs@Se composite, which is used as the positive electrode in lithium-selenium batteries. According to the synthesized substance, it is extremely homogenous and favors easy selenium loading. This composite's electrochemical performance was evaluated, and it demonstrated good rate performance (294 mA h g $\mathrm{m}^{-1}$ at $50 \mathrm{~mA} \mathrm{~g}^{-1}$ and $104 \mathrm{~mA} \mathrm{~h} \mathrm{~g}^{-1}$ even at $2500 \mathrm{~mA} \mathrm{~g}^{-1}$ ) and cyclic performance $\left(270 \mathrm{~mA} \mathrm{~h} \mathrm{~g}^{-1}\right.$ even after 100 cycles). The improved electrochemical performance owes to the rapid intercalation/de-intercalation of $\mathrm{Li}^{+}$into the CSs@Se composite and the decreased generation of undesirable soluble-polyselenides.

Author Contributions: Conceptualization, M.K. and X.D.; methodology, M.K. and X.D.; software, H.Z. and X.M.; validation, M.K. and Y.W.; formal anaysis: Y.W.; resources: X.D. and Y.W.; data curation: M.K.; writing—original draft preparation: M.K.; writing—review and editing: Y.W. and X.D.; visualization, X.D.; supervision, Y.W.; project administration, X.D. All authors have read and agreed to the published version of the manuscript.

Funding: This research was funded by the National Natural Science Foundation of China (NSFC, Grant No. 11874282, 11604245,11981240429), the Six Talent Peaks Project in Jiangsu Province (Grant No. 2019-XNY-074), and the Vice President Project of Industry-University-Research Cooperation in Science and Technology of Jiangsu Province (Grant No. BY2020675) and Young and middle-aged academic leader of "Qinglan Project" of universities in Jiangsu Province (2021).

Data Availability Statement: The data presented in this study are available on request from the corresponding author.

Acknowledgments: We all appreciate Pengfei He for his advice and help. We also thank the Wei Guan for his help for the samples measurement.

Conflicts of Interest: The authors declare no conflict of interest.

\section{References}

1. Shen, L.; Uchaker, E.; Zhang, X.; Cao, G. Hydrogenated $\mathrm{Li}_{4} \mathrm{Ti}_{5} \mathrm{O}_{12}$ Nanowire Arrays for High Rate Lithium Ion Batteries. Adv. Mater. 2012, 24, 6502-6506. [CrossRef]

2. Zhu, Z.; Wang, S.; Du, J.; Jin, Q.; Zhang, T.; Cheng, F.; Chen, J. Ultrasmall Sn Nanoparticles Embedded in Nitrogen-Doped Porous Carbon As High-Performance Anode for Lithium-Ion Batteries. Nano Lett. 2013, 14, 153-157. [CrossRef]

3. Goodenough, J.B.; Kim, Y. Challenges for rechargeable Li batteries. Chem. Mater. 2010, 22, 587-603. [CrossRef]

4. Armand, M.; Tarascon, J.M. Building better batteries. Nature 2008, 451, 652-657. [CrossRef] [PubMed]

5. Sun, Y.-K.; Myung, S.-T.; Park, B.-C.; Prakash, J.; Belharouak, I.; Amine, K. High-energy cathode material for long-life and safe lithium batteries. Nat. Mater. 2009, 8, 320-324. [CrossRef] [PubMed]

6. Bruce, P.G.; Freunberger, S.A.; Hardwick, L.J.; Tarascon, J.M. Li-O 2 and Li-S batteries with high energy storage. Nat. Mater. 2012, 11, 19-29. [CrossRef]

7. Mikhaylik, Y.V.; Akridge, J.R. Polysulfides shuttle study in the Li/S battery system. J. Electrochem. Soc. 2004, 151, A1969-A1976. [CrossRef]

8. Yang, C.-P.; Yin, Y.-X.; Guo, Y.-G. Elemental Selenium for Electrochemical Energy Storage. J. Phys. Chem. Lett. 2015, 6, 256-266. [CrossRef] [PubMed]

9. Abouimrane, A.; Dambournet, D.; Chapman, K.W.; Chupas, P.J.; Weng, W.; Amine, K. A New Class of Lithium and Sodium Rechargeable Batteries Based on Selenium and Selenium-Sulfur as a Positive Electrode. J. Am. Chem. Soc. 2012, 134, 4505-4508. [CrossRef] [PubMed]

10. Yang, C.-P.; Xin, S.; Yin, Y.-X.; Ye, H.; Zhang, J.; Guo, Y.-G. An Advanced Selenium-Carbon Cathode for Rechargeable LithiumSelenium Batteries. Angew. Chem. 2013, 125, 8521-8525. [CrossRef] 
11. Cui, Y.; Abouimrane, A.; Lu, J.; Bolin, T.; Ren, Y.; Weng, W.; Sun, C.; Maroni, V.A.; Heald, S.M.; Amine, K. (De)Lithiation Mechanism of Li/SeSx $(x=0-7)$ Batteries Determined by in Situ Synchrotron X-ray Diffraction and X-ray Absorption Spectroscopy. J. Am. Chem. Soc. 2013, 135, 8047-8056. [CrossRef] [PubMed]

12. Liu, L.; Hou, Y.; Wu, X.; Xiao, S.; Chang, Z.; Yang, Y.; Wu, Y. Nanoporous selenium as a cathode material for rechargeable lithium-selenium batteries. Chem. Commun. 2013, 49, 11515-11517. [CrossRef] [PubMed]

13. Zhang, Z.; Yang, X.; Wang, X.; Li, Q.; Zhang, Z. TiO2-Se composites as cathode material for rechargeable lithium-selenium batteries. Solid State Ion. 2014, 260, 101-106. [CrossRef]

14. Han, K.; Liu, Z.; Ye, H.; Dai, F. Flexible self-standing grapheme-Se@CNT composite film as a binder- free cathode for rechargeable Li-Se batteries. J. Power Sources 2014, 263, 85-89. [CrossRef]

15. Liu, Y.; Si, L.; Zhou, X.; Liu, X.; Xu, Y.; Bao, J.; Dai, Z. A selenium-confined microporous carbon cathode for ultrastable lithium-selenium batteries. J. Mater. Chem. A 2014, 2, 17735-17739. [CrossRef]

16. Zhang, J.; Zhang, Z.; Li, Q.; Qu, Y.; Jiang, S. Selenium encapsulated in to interconnected polymer- dervived porous carbon nanofibre webs as a cathode materials for lithium- selenium batteries. J. Electrochem. Soc. 2014, 161, A2093-A2098. [CrossRef]

17. Han, K.; Liu, Z.; Shen, J.; Lin, Y.; Dai, F.; Ye, H. A Free-Standing and Ultralong-Life Lithium-Selenium Battery Cathode Enabled by 3D Mesoporous Carbon/Graphene Hierarchical Architecture. Adv. Funct. Mater. 2014, 25, 455-463. [CrossRef]

18. Li, Z.; Yuan, L.; Yi, Z.; Liu, Y.; Huang, Y. Confined selenium within porous carbon nanospheres as cathode for advanced Li-Se batteries. Nano Energy 2014, 9, 229-236. [CrossRef]

19. Qu, Y.; Zhang, Z.; Jiang, S.; Wang, X.; Lai, Y.; Liu, Y.; Li, J. Confining selenium in nitrogen-containing hierarchical porous carbon for high-rate rechargeable lithium-selenium batteries. J. Mater. Chem. A 2014, 2, 12255-12261. [CrossRef]

20. Zhang, J.; Fan, L.; Zhu, Y.; Xu, Y.; Liang, J.; Wei, D.; Qian, Y. Selenium/interconnected porous hollow carbon bubbles composites as the cathodes of Li-Se batteries with high performance. Nanoscale 2014, 6, 12952-12957. [CrossRef]

21. Liu, L.; Wei, Y.; Zhang, C.; Zhang, C.; Li, X.; Wang, J.; Ling, L.; Qiao, W.; Long, D. Enhanced electrochemical performances of mesoporous carbon microsphere/selenium composites by controlling the pore structure and nitrogen doping. Electrochim. Acta 2014, 153, 140-148. [CrossRef]

22. Jia, M.; Mao, C.; Niu, Y.; Hou, J.; Liu, S.; Bao, S.; Jiang, J.; Xu, M.; Lu, Z. A selenium-confined porous carbon cathode from silk cocoons for Li-Se battery applications. RSC Adv. 2015, 5, 96146-96150. [CrossRef]

23. Wang, F.; Wu, X.; Li, C.; Zhu, Y.; Fu, L.; Wu, Y.; Liu, X. Nanostructured positive electrode materilas for post-lithium ion batteries. Energy Environ. Sci. 2016, 9, 3570-3611. [CrossRef]

24. Jiang, Y.; Ma, X.; Feng, J.; Xiong, S. Selenium in nitrogen-doped microporous carbon spheres for high-performance lithiumselenium batteries. J. Mater. Chem. A 2015, 3, 4539-4546. [CrossRef]

25. Peng, X.; Wang, L.; Zhang, X.; Gao, B.; Fu, J.; Xiao, S.; Chu, P.K. Reduced grapheme oxide encapsulated selenium nanoparticles for high-power lithium-selenium battery cathode. J. Power Sources 2015, 288, 214-220. [CrossRef]

26. Kundu, D.; Krumeich, F.; Nesper, R. Investigation of nano-fibrous selenium and its polypyrrole and grapheme composite as cathode material for rechargeable Li-batteries. J. Power Sources 2013, 236, 112-117. [CrossRef]

27. Cui, Y.; Abouimrane, A.; Sun, C.-J.; Ren, Y.; Amine, K. Li-Se battery: Absence of lithium polyselenides in carbonate based electrolyte. Chem. Commun. 2014, 50, 5576-5579. [CrossRef] [PubMed]

28. Luo, C.; Xu, Y.; Zhu, Y.; Liu, Y.; Zheng, S.; Liu, Y.; Langrock, A.; Wang, C. Selenium@Mesoporous Carbon Composite with Superior Lithium and Sodium Storage Capacity. ACS Nano 2013, 7, 8003-8010. [CrossRef] [PubMed]

29. Trevor, M.; Huiyang, F.; Han, D.; Meicheng, L. The Detailed Evolution of Carbon Spheres by Hydrothermal Method. Int. J. Photoenergy 2016, 2016, 9057412.

30. Min, L.; Wei, L.; Shouxin, L. Control of the morphology and chemical properties of carbon spheres prepared from glucose by a hydrothermal method. J. Mater. Res. 2012, 27, 1117-1123.

31. Liu, L.; Hou, Y.; Yang, Y.; Li, M.; Wang, X.; Wu, Y. A Se/C composite as cathode material for rechargeable lithium batteries with good electrochemical performance. RSC Adv. 2014, 4, 9086-9091. [CrossRef]

32. Huang, D.; Li, S.; Luo, Y.; Xiao, X.; Gao, L.; Wang, M.; Shen, Y. Graphene oxide-protected three dimensional Se as a binder-free cathode for Li-Se battery. Electrochim. Acta 2016, 190, 258-263. [CrossRef]

33. Lee, J.T.; Kim, H.; Nitta, N.; Eom, K.S.; Lee, D.C.; Wu, F.; Yushin, G. Stablization of selenium cathodes via in situ formation of protective solid electrolyte layer. J. Mater. Chem. A 2014, 2, 18898-18905. [CrossRef]

34. Zhang, Z.; Yang, X.; Guo, Z.; Qu, Y.; Li, J.; Lai, Y. Selenium carbon/carbon-rich core-shell composites as cathode materials for rechargeable lithium-selenium batteries. J. Power Sources 2015, 279, 88-93. [CrossRef]

35. Zhang, J.; Xu, Y.; Fan, L.; Zhu, Y.; Liang, J.; Qian, Y. Graphene-encapsulated selenium/ployaniline core- shell nanowires with enhanced electrochemical performance for Li-Se batteries. Nano Energy 2016, 13, 592-600. [CrossRef]

36. Zeng, L.; Wei, X.; Wang, J.; Jiang, Y.; Li, W.; Yu, Y. Flexible one dimensional carbon selenium composite nano-fibers with superior electrochemical; performance for Li-Se/Na-Se batteries. J. Power Sources 2015, 281, 461-469. [CrossRef]

37. Asif, M.; Rashad, M.; Ali, Z.; Ahmed, I. Synthesis of ternary metal oxides as positive electrodes for Mg-Li hybrid ion batteries. Nanoscale 2020, 12, 924. [CrossRef]

38. Ding, X.L.; Zhao, H.D.; Liang, D.W.; He, P.F. Enhanced electrochemical peeformance of silicon monoxide anode materials prompted by germanium. Mater. Chem. Phys. 2021, 267, 124611. [CrossRef] 
39. Ding, X.L.; Liang, D.W.; Ai, X.; Zhao, H.D.; Zhang, N.; Chen, X.J.; Xu, J.H.; Yang, H.H. Synergistic Lithium Storage in Silica-Tin Composites Enables a cycle-Stable and High-Capacity Anode for Lithium-Ion Batteries. ACS Appl. Energy Mater. 2021, 4, 2741-2750. [CrossRef]

40. Ding, X.L.; Liang, D.W.; Zhao, H.D. Enhanced electrochemical Performance Promoted by Tin in silica Anode materials for Stable and High-capacity Lithium-ion Batteries. Materials 2021, 14, 1071. [CrossRef] 